\title{
Coproduced game-changing in transformative social innovation: reconnecting the "broken city" of Rio de Janeiro
}

\author{
$\underline{\text { Carla Cipolla }}^{1}, \underline{\text { Rita Afonso }}^{1}, \underline{\text { Bonno Pel }}^{2}, \underline{\text { Roberto Bartholo }}^{l}, \underline{\text { Edison Renato Silva }}^{1}$ and Domício Proença Júnior $^{1}$
}

\begin{abstract}
Social innovation is gaining attention for its potential for system transformations. It is often initiated by grassroots collectives, which can become successful through support from other actors and through certain game-changing events or developments. We highlight how transformative social innovation is a highly dispersed, coproduced process of changing social relations. This coproduction is unfolded through a case of interacting interventions in the socio-spatial structure of the city of Rio de Janeiro. Frequently referred to as a "broken city," the city suffers from various social challenges related to the socio-spatial cleavages between the welldeveloped and the marginalized areas, the favelas. Following a nested-case approach, we describe two policy measures and three social innovation initiatives intended to reconnect the broken city. We analyze their effects as well as their various interactions. The findings give reasons for considering the policy measures as "game-changers" that allow new courses of play. Still, the key observation about these intertwined socio-spatial interventions is that the broken city is undergoing more dispersed game-changing. Further observing how the reconnections constitute different kinds of changing mobility, we conclude with reflections on mobility-related game-changing.
\end{abstract}

Key Words: coproduction; game-changers; social innovation; socio-spatial relations; transformation

\section{INTRODUCTION}

Social innovation is recently gaining attention for its potential for system transformations (Witkamp et al. 2011, Moore et al. 2014, Klein et al. 2016). Sharing schemes, energy cooperatives, food sovereignty initiatives, and citizen labs are but a few prominent examples of the new ways of doing, organizing, and knowing that are currently developing as alternatives to unsustainable or otherwise dysfunctional modes of production and consumption. The examples testify to how social innovation is a dimension of socio-technical innovation that is of no less importance than the much-celebrated new technologies (Franz et al. 2012). The examples also bring out why transformative social innovation, understood as changes in social relations, is worthwhile considering the ways in which it challenges, alters, or replaces dominant institutions. We follow Avelino et al. (2017) in this focus on transformative social innovation (TSI).

Social innovation on this transformative account is commonly understood as innovation stemming from outsiders to the dominant institutional constellation. In Moulaert et al. (2013) and Klein et al. (2016) this applies almost by definition because social innovation is considered a response to structural imbalances and inequalities and as empowerment of marginalized groups. Nicholls and Murdock (2012) usefully specify how social innovation typically involves blurring boundaries between institutional logics, relying on hybrid institutions and institutional entrepreneurs that operate at the edges of existing institutions. Also the perspectives of grassroots innovation (Seyfang and Smith 2007, Seyfang and Haxeltine 2012), and "social niches" (Witkamp et al. 2011, Dóci et al. 2015) attribute social innovation largely to subaltern, extra-institutional actors. Following the typically systems-theoretical views through which TSI is explored, it is therefore crucial to gain understanding of the broader systemic dynamics and framework conditions that allow the outsider initiatives to have transformative impacts. Institutionalization into markets and governments (CajaíbaSantana 2014) is important, but the breakthrough of bottom-up action also depends on the ever-dynamic selection environments of coupled social-technological-ecological systems (Folke et al. 2010, Grin et al. 2010, Moore and Westley 2011).

We seek to contribute to this special feature, which explores this systemic dimension to transformative agency through the concept of the "game-changer". This concept attempts to grasp the system disturbances that push a system into the innovative "back loop" phases (Moore and Westley 2011), and is similar to the notion of the "landscape" developments in the multilevel perspective on transitions. The landscape category indicates the broader, macrolevel system dynamics that shape both the emergence of niches and the endogenous renewal of socio-technical regimes (Geels and Schot 2007, Grin et al. 2010). The game-changer metaphor reflects recent criticisms that challenge the determinist assumptions surrounding this category (Jørgensen 2012, Avelino et al. 2017). As will be exposed, it recasts landscape developments as shifts in ongoing games, unstable action fields, and situated play. This contribution underlines that game-changers are coproduced phenomena. Following Swilling (2016) and Pel et al. (2016), we think that any understanding of game-changers needs to be informed by an intimate knowledge of the game-changing process in which certain developments, events, actors, or institutions are acquiring their game-changing powers.

Our understanding of game-changing in TSI is substantiated through a case in which its coproduced nature is particularly apparent: the "broken city" (Ventura 1994) of Rio de Janeiro. This telling notion expresses how the socio-spatial cleavages between its developed areas and the informal settlements (the favelas and the peripheral areas more generally) have become a key systemic vulnerability. The broken city, a predicament faced by many other Latin American cities as well, is a multidimensional transformation challenge, involving problems of social exclusion, violence, unsustainable development, poverty, and weakened rule of law. Taking the recently emerging process of reconnection as an exemplar, our case analysis shows TSI is a highly dispersed

${ }^{1}$ Universidade Federal do Rio de Janeiro, ${ }^{2}$ Université Libre de Bruxelles 
process of changing socio-spatial relations. Through a nestedcase approach we describe several policy measures as apparent game-changers and three social innovation initiatives that crucially coproduced the process of socio-spatial reconnection. Our analysis is led by the following questions: In what ways have the social innovations and policy measures achieved reconnections in the broken city, and how have they interacted? The responses to these questions allow us to answer the main question: How was the game-changing coproduced?

\section{THE BROKEN CITY}

Since the 1980s, inhabitants of Rio de Janeiro have observed the break-up of their city, through the increased disparity between the developed areas and the impoverished informal settlements (favelas), a cleavage locally also referred to as the disparity between "asphalt" and "hill" areas. Rio de Janeiro has 6 million inhabitants, 1.4 million of whom are living in its 763 favelas (IPP 2014). Because these are spread throughout the city, the associated social inequalities are apparent to all. Zuenir Ventura's (1994) Broken City reported drug traffickers' augmenting power over the favelas, involving widespread violence, extortion, and ongoing drug wars. His groundbreaking exposé of the oppressive conditions in the favelas raised public awareness, and led to various attempts to reincorporate and regenerate these areas through urban planning and welfare policies. "Broken city" became shorthand for a whole set of problems as diagnosed through lenses of social exclusion (Rodrigues and Orlandi 2010), urban violence (Koonings and Kruijt 2013), urban geography (Deffner 2011), and urban democracy (Carvalho 1995). Ventura (1994) argued that the city would soon be split into two separate realities, segregating social classes, neighborhoods, and cultural groups into increasingly limited interaction. The separation between hill and asphalt would escalate, even in the situations of geographical neighbors, such as those in the South Zone of Rio (IPP 2014).

The broken city diagnosis clarifies how the problems of the favelas are highly relevant for the topic of game-changing in TSI. First, it instructively identifies Rio de Janeiro's various urban problems as different dimensions of a complex systemic problem. Distinct problems like poverty, violence, and social exclusion are recast as manifestations of an urban system caught up in a vicious cycle of disintegration. Ultramari and Rezende (2007:50) describe the process of system collapse as a "silent and huge slow accident," a systemic trend that is particularly difficult to break loose from for lack of a clear system state to restore or a model to work toward. Second, the broken city diagnosis asserts a highly dispersed problem of broken socio-spatial relations, requiring socio-spatial reconnections to make the city more resilient. Third, the broken city diagnosis speaks to the particular topic of gamechanging. It helps to articulate the urban problems as a game with unfavorable outcomes, locked-in strategies, yearnings for gamechanging, and initiatives by different players toward new lines of play.

Key players but not necessarily the leading players in the dramatic course of play are the favela inhabitants. To them, the favelas are housing solutions (Lacerda 2015). Their informal settlements have for a long time formed part of Rio de Janeiro, as the regular housing capacity repeatedly fell short in accommodating successive immigration waves. By $1950,7 \%$ of the population were already in favelas. Since then, the number of people flowing into the informal settlements has augmented dramatically, especially in the last decades. The economic developments that spurred massive migration toward the urban centers can be considered game-changers that shaped the course of play until today: the favelas became too sizeable to be ignored. Because favelas stem from illegal occupations, various governmental organizations have become involved with them. As described extensively elsewhere, the rampant favelas have led authorities into an apparent game against nature, in which the containment of undesirable urbanization was pursued through demolition and eviction programs. Apart from this role of tough arbiters, governmental actors were also important players as providers of public services (sanitation, public healthcare, energy, education). This course of play through urban planning and social policy schemes remained limited, however, as the illegal status of the settlements left them outside the playing field. A third group of actors that became increasingly influential on the course of play were the drug lords and vigilantes who seized the power vacuum in the informal zones. They offered revenue flows, protection, and other services to favela citizens left largely to their own devices. These self-appointed authorities hampered governmental provision of infrastructural improvements and services even after (partial) legalization of informal settlements. Tariffs for truckborne water, gas for cooking, siphoned electricity, and pirate cable $\mathrm{TV}$, among others, were substantial sources of income for the drug lords.

The interactions between these groups display locked-in strategies. Public authorities became gripped in strategies of denial, retreat, and repression, especially as the drug lords and vigilantes evoked adversarial approaches to the favelas. The latter basically profited from the situation of illegality and isolation, and sought to maintain it. Meanwhile, favela inhabitants felt increasingly isolated, stigmatized, and abandoned by public authorities, and adversarial relations toward government worsened as police raids and evictions become more violent and disregarding of civil rights. This escalating course of play involved not only the aforementioned groups of "players" and the playing field of the favela territories. It crucially extended well beyond the problematic areas, affecting the socio-spatial relations between the favelas and the rest of the city. The favelas and their surroundings became increasingly dangerous places to be because of drug lord or vigilante authority, who ruled by use of force. In and outbound travel were subject to controls, curfews, exclusions, and tolls, and passers-by became targets for robbery. This situation of impeded mobility was a fact of life for all cariocas (Rio de Janeiro inhabitants) especially in the north zone, away from the tourist area of the city. Conventional approaches to urban mobility in Brazil have limited this issue to physical transportation (e.g., Magagnin and Silva 2008). However, this downplays the symbolic-cultural dimensions of the impeded mobility. The described stigmatization of the favelas and its inhabitants, the generalized fear, and the tendencies toward segregation and retrenchment indicate a broader problem of hampered socio-spatial relations.

\section{COPRODUCED GAME-CHANGING: TRANSFORMING SOCIO-SPATIAL RELATIONS}

The broken city diagnosis as proposed by Ventura (1994) brings forward a systemic view on the social problems associated with 
Rio de Janeiro's favelas. It informs an understanding of the game and its playing field, players, stakes, and strategies, also expressing the yearning for game-changing to this undesirable course of play. As underlined by Smith and Stirling (2010), such delineations of the playing field are neither obvious nor innocent, however. These system demarcations convey assumptions about why and how the game should be changed, and which stakes count the most. Particularly important assumptions for our topic are those suggesting whose move it is to initiate a game-changer, whose agency the game-changing is to be ascribed to. This is a very sensitive issue: many initiatives toward game-changing have already been undertaken over the heads of the favela inhabitants, reducing them to passive players or even spectators. As detailed in a critical discourse analysis by Lacerda (2015), political and media utterances on the favela game-changing tend to selectively highlight and downplay the agency of players.

Our theorization of game-changing in TSI should not silently presuppose to which agents this should be attributed. A first step in our conceptualization is therefore to underline that the broken city is a highly dispersed and systemic challenge. It is characterized by impeded socio-cultural mobility and deteriorating sociospatial relations. Along this diagnosis, the favelas can be appreciated as exemplars of Foucault's "heterotopias", i.e., as cast aside and dismissed "other spaces." In this view, the favelas are not considered as isolated sites of problems, but rather as parts of a problematic system of social-spatial relations through which both the "other" and the "regular" spaces acquire their function and meaning (Foucault and Miskowiec 1986). The corresponding TSI then amounts to a process in which these socio-spatial relations are drastically changed, and in which the broken city undergoes reconnections. This understanding of TSI gamechanging in terms of changing socio-spatial relations coincides with territorial development accounts of social innovation. Moulaert (2009:17) tellingly highlights how this involves the "building of communication channels between privileged and disfavoured citizens within urban society."

Van Dyck and van den Broek (2013) remind us that these changes in socio-spatial relations have important material dimensions that are often neglected in social innovation research. This helps to avoid anthropocentric understandings of the game-changing in which space is reduced to a passive background to game-changing actors and institutions. Taking the system diagnosis of problematic socio-spatial relations seriously, we need to account for the many dimensions of these relations and the many kinds of game-changers that could intervene in them. As described below, the socio-spatial relations involved not only various actors and organizations as players, but also the identities of areas, the material changes in transport infrastructures, and the evolution of communication channels. Pel et al. (2016) sketch similarly in this special feature how socially innovative agency emerged through the reconsideration of prevailing social-technologicalecological relations in the Belgian electricity system. Following Avelino et al. (2017), a second element in our conceptualization is thus to conceive of TSI as a process of changing social relations in a social-material context.

A further implication of the socio-spatial, multidimensional understanding of the broken city course of play is that the process of game-changing in TSI is not attributed exclusively to isolated game-changers. Avelino et al. (2014:12) define these as "macrodevelopments that are perceived to change the (rules, fields and players in the) 'game' of societal interaction." Apparent examples of such macrodevelopments were the migration waves into Rio de Janeiro, or the policy measures by governmental players aimed to reincorporate favelas into the urban social fabric. Still, the so multidimensional and dispersed nature of the broken city game suggests that any game-changing will emerge from a multitude of interventions in the socio-spatial relations. In line with Swilling (2016) and Pel et al. (2016) in this special feature, we understand game-changers as a coproduced phenomenon. Other than seeking to identify game-changer events, developments, and actors that change the course of play as exogenous and determining forces, we consider that any of those acquiring their game-changing powers in processes of game-changing. Social innovation initiatives developed by favela inhabitants are thus acknowledged as coproducers of game-changing. We thus underline how the game-changer concept recasts the similar notion of the landscape developments in the multilevel perspective on transitions, which indicates the broader, macrolevel system dynamics that shape both the emergence of niches and the endogenous renewal of socio-technical regimes (Geels and Schot 2007, Grin et al. 2010). Our understanding of coproduced game-changers is very much in line with actor network theory accounts that challenge the determinist assumptions surrounding the landscape category (Jørgensen 2012, Avelino et al. 2014). Instead we foreground the dispersed and coproduced game-changing processes through which socio-spatial relations are transformed, and through which the broken city is reconnected in various sites and on various dimensions.

\section{METHOD: A NESTED CASE STUDY}

Considering that we aim to study ongoing, unstable, and unique processes, case study was the preferred method for its capacity to generate in-depth understandings about phenomena (Yin 1994). Aiming to develop the game-changer concept rather than apply or confirm it as a theory, the study has taken an exploratory approach. More specifically, we developed our case through a nested-case approach. Such focus on nested, interconnected units of analysis rather than singular focal actors (Yin 1994) is a methodological choice that matches our theoretical assumptions of dispersed agency and complex processes of transformation ( $\mathrm{Cf}$. Byrne 2005). Our case study describes two policy measures and three social innovation initiatives intended to reconnect the broken city. Conducted between August and December 2014, the study involved semistructured interviews with key actors, document analysis (academic publications, newspaper articles, reports from research organizations, and policy documents), and observation of the three social innovation initiatives in their day to day activities. We describe their effects on socio-spatial relations, but also their mutual interactions. The latter analysis of intersections between cases (Pel 2014) helps to elicit the coproduction of game-changing.

UPP (Pacifying Police Unit) program, which aims to install community policing in favelas once dominated by drug lords and vigilantes (Willis and Prado 2014), and Rio Estado Digital ("State of Rio Digital"), on provision of free Internet access for favela residents (Holmes 2009), have both been portrayed as gamechanging interventions. These game-changers paved the way for, or as we will demonstrate, were coproducing a game-changing 
process with the three following social innovation initiatives: first, Papo Reto ("Straight Talk"), a social network providing alerts about violence in the city's largest favela area Complexo do Alemão. Second, the Coletivo Norte Comum is a collective for cultural production by residents from the northern outskirts, as outsiders from the mainstream cultural circuit. The third, FLUPP (Literary Festival of the UPPs), was a literature festival in the favelas aimed at boundary-crossing dialogue in Rio. The Favelas' Observatory (Observatório de Favelas 2017) highlighted the importance of these three social innovation initiatives, whose part in the game-changing will be further analyzed below.

\section{COPRODUCED GAME-CHANGING}

For reasons of conciseness and in line with our nested-case research design, our empirical account will not provide in-depth descriptions of the aforementioned five interventions in the broken city. Following our research questions, we subsequently highlight how socio-spatial relations were changed by the two policy measures as apparent game-changers and the three social innovation initiatives as other relevant elements in the gamechanging. Subsequently we identify the interactions between the five interventions and synthesize these observations into overall conclusions on coproduced game-changing.

\section{Two apparent game-changers}

The Pacifying Police Units (UPP) starting in 2008 can be considered as a game-changer because this intervention program forcefully drove away from the prevailing course of play. The UPP project is a law enforcement and social services program promoted by the Rio de Janeiro State Government in collaboration with the Municipal and Federal Governments. UPP amounts to a new concept in the provision of security, deploying decisive force to remove control from the drug lords in favela territories by ensuring police presence and basic social services. Communities are recovered by pacification, which plays a key role in social and economic development of the communities; it favors the development of public services, infrastructure, social, sporting, and cultural projects, private investment, and opportunities (UPP 2017a). According to the responsible Security Secretary, "it is not just a security project; it is a State policy of life improvement and hope development to the people of Rio de Janeiro"(UPP 2017b).

The pacification changed socio-spatial relations in various ways. It involved changes in the balance of power and restoration of rule of law, restoration of trust relations, developed social services provision within the favela areas, and facilitated inbound and outbound travel. These were game-changing changes for the interactions between residents of the favelas and those from other neighborhoods.

The UPP approach begins in the wake of armed repossession of a favela territory with the support of substantial, battalion-sized and heavily equipped units of the Brazilian Army or Marines. Once the area is cleared and held for long enough to prevent any attempt at repossession by the drug lords, an independent pacifying unit is put in place. It begins by destroying and repurposing locations and structures that have been run by the drug lords (Silva et al. 2015). As partnerships between local residents and law enforcement institutions (UPP 2017a), UPPs are subsequently meant to allow favela residents to take ownership of their territories. The UPPs crucially involve the removal of arbitrary controls or extortion, returning these spaces to the city and the residents deprived of this freedom to move (Silva 2011). Because favela residents mostly work outside the favelas, this change in the social-material conditions for mobility is of particular transformative significance to them.

In 2017, there is in total 38 UPPs with approximately 9500 police officers (UPP 2017c), almost a fifth of the 50,000 members of Rio de Janeiro State's Polícia Militar (police patrols). Because this policy has reduced violent deaths and homicides, it might well be sustained (Misse 2014). Moreover, the social-materially transformed accessibility has generated unprecedented mobility flows and exchanges. For tourists and nonresidents, the regained accessibility has unveiled a hidden reality. Conversely, favela residents themselves could easier connect with other cariocas and visitors, and develop business opportunities (Burgos et al. 2011). The pacification thus involved heavy physical-material interventions, transformations in power relations, and a gradual shift in organization, but also major changes in accessibility and the associated new patterns of relationship and exchange.

The second policy intervention can also be considered as a gamechanger, albeit one in the form of changes in technology and communication channels. In 2008 the state government together with several universities initiated the "Rio State Digital" project. A key element was the provision of free Internet, with 2.5 million beneficiaries ( $15 \%$ of the state population) until 2011. The 900 $\mathrm{Mb}$ to $1 \mathrm{~Gb} / \mathrm{s}$ bandwidth is present in the favelas (South and North Zones), in tourist attractions, and in the outlying areas of the Rio Metropolitan Region. Beyond the free Internet access, this digital inclusion program was above all "an educational project, of knowledge in communities, culture, information and qualification opportunities" (Governo do Rio de Janeiro 2011). The project developed web site platforms for professional courses (telemarketer, office assistant, sales promoter, assembly, and computer maintenance), e-government (updating documents, access and scheduling to city hall, state and federal government organizations), and entrepreneur support (laws and regulations), as well as shortcuts to job sites.

The broadly scoped digital inclusion program changed sociospatial relations in various ways. It was first of all an intervention that technically facilitated communication and dialogue between favela and "asphalt," opening up relations within the city and reaching out to the rest of Brazil and the world. Important changes in socio-spatial relations between residents and the state took place in the form of increased access to rights, services, and employment possibilities. More broadly, the program afforded socio-cultural mobility (Sorj and Guedes 2005). The integration into the information and communications technology revolution also balanced the production of news about and dominant images of the favela, which used to be available only through mainstream media. A new communication game was started in which favela inhabitants began to articulate their own standpoints and realities, to "asphalt" residents and government. This emancipation involved both the gaining of credibility as sources of reliable information for others as well as changing selfperceptions. The Director of the Favelas' Observatory stated that "on the streets, a young man from the favela is just that, but he is not acknowledged as a citizen (...) Now, on his Facebook, he shows and asserts himself, identifies his preferences, sets out his conflicts, all because he does not feel alone." 


\section{Broader game-changing: three social innovation initiatives}

The above two policy measures can be considered crucial gamechangers that impacted various dimensions of socio-spatial relations. Crucially however, other actors developed initiatives that contributed to the game-changing process by using cultural production and new communication flows for new patterns of play between different areas of the city.

The first initiative, Coletivo Papo Reto or "straight talk collective," developed in 2014 as a network of independent communicators. Emerging in Rio's two biggest complexes of adjacent favelas, Alemão and Penha, their declared goal was to spread news about events, protests, and violence, acting as a channel of critical communication about favela realities from their residents' point of view. The founder declared that its main aim was to call for a reflection about "up to what point the claims of mainstream media are true." The initiative manages a WhatsApp group of hundreds of residents, merchants, and motorcycle-taxi drivers, sharing real time information about conflicts in the favela. Also their Facebook and Twitter accounts are platforms for podcasts about actual developments, often criticizing the priorities and practices of police activities. By asserting itself as a relevant voice, the initiative became acknowledged across the broken city divide. Members represented it at academic, cultural, and communication events, and in 2016 one of its members was hired for the left party's campaign for the mayor's office. The group also gained international visibility, receiving support and training from and collaborating with human rights NGOs such as Amnesty International and the "black lives matter" movement.

The initiative was inherently related to the aforementioned gamechanging policy interventions. The collective was born specifically to question the excessive policing order established by the UPP, involving a curfew, among other things. As the conflicts on the drug trafficking intensified, the WhatsApp group was created as a security information system beyond the UPP, indicating in real time where it is safe or unsafe to go. As the collective gained respect as an alternative media channel, it thus enacted a new course of play. Favela residents became news subjects rather than objects, and therewith cocreators of the social-spatial order.

The second initiative, Coletivo Norte Comum, was created in 2011 as a network of cultural producers. Living in the poorer parts of the city yet seeking to engage in high-quality cultural productions, the collective emerged from shared dissatisfaction with the local lack of channels for cultural expression. As one of their participants stated the following:

\begin{abstract}
The northern zone has nothing; no theatre, bars, cinemas, venues for shows. And the city hall opened up calls to use those in the south ... we never won ... the same producers always won. When we wanted to meet our friends, we would pick up one or two buses and stop in the city center or the south to meet friends who live on the same street, in the same building sometimes. The Norte Comum came up with this idea: Why do people go so far away to have fun? Why don't we produce here what we are going to do in the south and central zones?
\end{abstract}

The collective intervened in socio-spatial relations by initiating cultural production in culture-deprived areas. In doing so they changed the map of cultural production, which typically reflected the problematic socio-spatial relations of the broken city. Their social innovation consists of the development of new centers of artistic-cultural citizenship. Adapting cultural products to the taste of a public outside the mainstream cultural circuit of Rio and finding innovative ways of gathering the resources needed to sustain their independent actions, they produce several cultural events. Their significance for changing social-spatial relations is simultaneously inward and outward. Regarding the first, the initiators actively share their skills, stimulating the organization of other local cultural events and empowering people to take on the cultural production and consumption in their own regions. Regarding the second, the collective can be seen to reverse the established patterns of relationship between the center and the outer areas. Through the dispersed emergence of cultural events, the hitherto peripheral North Zone and other areas could start to act as centers or nodes of cultural production and consumption. The initiative reasserted peripheral areas as relevant destinations.

The third initiative, FLUPP, is a literary festival that started in 2012. It is an independently organized initiative that takes place in favelas pacified through the UPP program. It was developed by a former resident based on the awareness that there were writers and poets in the favelas, but that they were marginalized: "we perceived a demand for a literary festival of great importance in the city able to include the diversity of territories, including the favela. The youth not only read, but they also like to write and we wanted to create a channel to generate opportunities for these young people."

When the UPP was implemented and the requisite sense of social security had grown, favela inhabitants considered the time ripe for the festival. It promotes dialogue between renowned and emerging fringe writers, also bringing the latter into contact with publishers. The festival stimulates "improbable dialogue" and fosters mutual learning by bringing together consumers and producers of literature in a "pacified" favela. In contrast with the traditionally rather elitist cultural events, FLUPP places the "ordinary," locally based authors and poets center stage.

Similar to Norte Comum, the FLUPP changes the map of cultural production in the broken city, and it intervenes in socio-spatial relations by challenging the prevailing cultural divisions. It allows neighborhoods to assert themselves as new nodes in the broken city. As a literary festival, it is highly symbolic of the pacified course of play that is facilitated through the UPP. Its significance for changing socio-spatial relations speaks particularly from the fact that the festival moves across the city toward newly pacified favelas, and from its virtual travelling. The festival brings in participants from all over the world, has substantial media coverage, and has an important dissemination component in its online offers of free e-books.

\section{Interactions}

The described five interventions already brought out various mutual interactions. Important parts of the game-changing process would be neglected if we limited the analysis to a summation of their independent impacts. Following a nested-case approach, the picture of game-changing is complete through the observation of interactions between cases. The multiple interactions between the policy measures and the social innovation initiatives can be summarized as follows: 
First, there are several instances in which the policy measures and social innovation initiatives developed symbiotically. Rio State Digital was intended to work as a flanking policy measure to the UPP pacification program. Both the increased sense of security brought by the latter and the communication channels changed by the former brought about reconnections in the broken city. The two policy measures also converged in the rapprochement between favela residents and the State, because they both facilitated the access to public services at the municipal, state, and federal levels. Their game-changing effects were mutually reinforcing toward new courses of play in which the favelas did not feature as problematic zones to be avoided but rather as neighborhoods to cultivate and to tap from.

Second, it is striking how the social innovation initiatives were in many ways carried by the two symbiotic policy measures. FLUPP can be considered the typical new course of play that was opened up by the game-changing policy interventions. Norte Comum emerged somewhat more independently from the UPP pacification program, but still it was a course of play that became more feasible through the gains in physical safety, the changing communication infrastructure, and the changing socio-spatial meanings accorded to the peripheral areas. The alternative media initiative of Papo Reto is similarly a course of play that was possible but very difficult to initiate without the socio-technical enabling of the Rio State Digital program.

Third, there are several examples of interactions that were not symbiotic and rather constituted mild divergences or even interferences between the policy measures and the social innovation initiatives. The most striking example of this was the emergence of Papo Reto as a critical countermovement against the repressive and unilateral approach of the UPP pacifications. Even if the two may eventually turn out as mutual reinforcements, this example does make it evident that the game-changing was contested. A similar critical attitude toward the game-changing can be observed with the Norte Comum initiative. Even if not explicitly going against the game-changing policy measures, they do underline that the reconnection of the broken city requires fundamental transformations in socio-spatial relations, and confrontation of deeply rooted beliefs about centers and peripheries.

\section{Conclusion: coproduced game-changing}

Summarizing the above observations, we can answer our research questions. In what ways have the social innovations and policy measures achieved reconnections in the broken city, and how have they interacted? How was the game-changing coproduced?

It has become evident that the policy measures provided the social-material opportunities for citizens to become protagonists of social-spatial reconnections in the city. They allowed new moves (increased safety), or allowed those to be more effective (creating communication facilities, among other things). The policies can thus be identified as game-changers, opening up new patterns of play. Still, it has also become apparent that these could only settle and be sustained through the play of other actors. The three social innovation initiatives exemplify various attempts from residents of favelas or peripheries to make use of these new opportunities. Sometimes they were largely complementary and compliant, but generally they did not simply follow the course of play set out for them. The social innovation initiatives also had independent significance as attempts to create new socio-cultural changes. Residents of marginalized areas sought to reshape the symbolic-cultural relations between favelas and asphalt, usually defined by segregation and stigmatization. The initiatives started new practices, on which participants recognize themselves as cultural producers and communicators. With this, they were able to position themselves and their marginalized localities as part of the cultural production processes in the city and to include their standpoints in the communication flows. It results in a multisided process of socio-spatial reconnections between different groups and areas, amidst which certain game-changing actors and events stand out. Figure 1 visualizes the relations between the two policybased game changers, the three social innovation initiatives, and their interventions into the socio-spatial relations in the broken city, theorized as a coproduced game-changing process.

Fig. 1. Coproduced game changing process and socio-spatial relations in the "broken city."

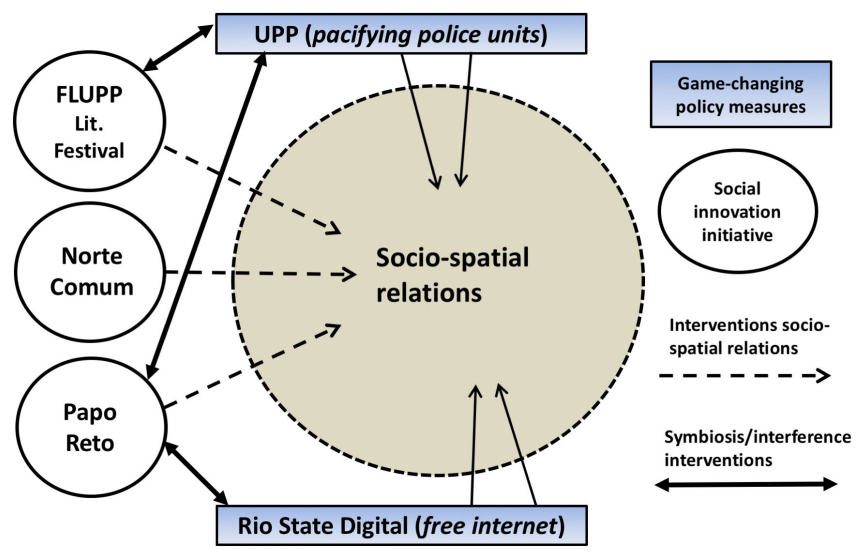

The social innovation initiatives and the policy measures can be seen to display largely reinforcing but also divergent changes in socio-spatial relations that make the reconnection in the broken city a highly dynamic process. The policy measures facilitate social innovation activities and unlock areas, but they also evoke contestation and countercultural expressions, which in turn gain recognition as cultural initiative, touristic spectacle, community development or urban novelty. This underlines how the reconnection of the broken city is a process of social-spatial transformation that is coproduced by largely symbiotic but also divergent forces.

Finally, this case of game-changing in transformative social innovation is particularly instructive for the various changes in socio-spatial relations and the multidimensional nature of the game-changing process. The game-changing was coproduced through changes in accessibility and safety, rule of law, trust relations, communication channels, identities of neighborhoods, cultural maps, international exposure, and community empowerment, among other things. The reconnection of the broken city involved changes in socio-spatial relations that were not only distributed across different groups of actors, but also across different dimensions of the socio-spatial cleavages at issue. 


\section{MOBILITY TRANSFORMATION AS A CHANGE IN SOCIO-SPATIAL RELATIONS}

Initiatives toward transformative social innovation need to be supported by game-changing macrodevelopments for them to become effective. The game-changer concept as proposed by Avelino et al. (2014) is an interesting metaphor through which to grasp those developments. It is similar to the theorized "landscape pressures" (Geels and Schot 2007) and "system disturbances" that push inert systems into the "back loop" phases of innovation and reconfiguration (Moore and Westley 2011). Compared to these notions of exogenous systems dynamics, the game-changer is a more immanent concept. It focuses on the contextual significance of macrodevelopments for situated actors in particular game situations. Rather than being decisive out of themselves, macrodevelopments can turn out as game-changers given a course of play and given players' understanding of it as a significant shift.

In line with this essentially relational understanding of gamechangers, we have underlined that such developments form part of coproduced game-changing. Our empirical analysis has substantiated this argument, while also helping to deepen our understanding of game-changers and game-changing. The broken city case showed two policy measures that can be considered as game-changers. In many ways these interventions altered the course of play, creating favorable conditions for social innovation initiatives to emerge. They allowed new moves (increased safety), or allowed those to be effective (creating communication facilities). On the other hand, the case analysis also demonstrated well how these game-changers were enmeshed in a game-changing process in which the social innovation initiatives were essential as well. The new lines of play were facilitated by the policy measures, but cannot be entirely ascribed to them. The game-changing capacity of the policy measures was supported and amplified by the many ways in which the social innovation initiatives experimented with, developed, and sustained new socio-spatial relations. These initiatives notably developed networks across the divides of the broken city, and challenged the spatial order that locked the favelas into their identity as "other spaces." In other words, the case suggests it is analytically fruitful to consider both the game-changing process as a whole and the distinct role of game-changers therein.

Finally, it can be considered that the sketched coproduction between policy measures and social innovation initiatives exemplifies the coming together of bottom-up and top-down agency. This convergence is crucial for TSI processes, as has been frequently discussed (Pradel Miquel et al. 2013). Indeed, the case appears to be an example of what has been called "bottom-linked" development (Eizaguirre et al. 2012, Moulaert et al. 2013) or "cocreation with citizens" (Voorberg et al. 2015). Such reading is reinforced by our presentation of the nested-case study, which broke down the game-changing process into policy measures, social innovation initiatives, and their interactions. It needs to be remembered however that juxtapositions of bottom-up and topdown easily reproduce the very divisions in the broken city that were at issue. Such interpretation neglects how the social innovation was not confined to the favelas, but rather changed their socio-spatial relations with other areas and therewith their identity as Rio de Janeiro's "other spaces." The bottom-up and top-down interpretation provides too static a view on the game- changing. Instead, as the "mobilities turn" in the social sciences (Urry 2007:6) elicits about our case, the game-changing revolved around changing social-spatial relations and around mobility. Ureta (2008) applies this lens in a case study on low-income families in another broken city, Santiago de Chile. His in-depth account of problematic socio-spatial relations shows how the social exclusion of these families manifests concretely in both excessive necessary mobility as well as a very limited capacity to move as they please. The brokenness and reconnection of Rio de Janeiro can similarly be understood in terms of changing conditions for mobility, connectivity, and access. Other than through static bottom-up and top-down accounts, the exclusion and inclusion of favela inhabitants is theorized to be shaped through a constantly evolving mobility system. Discussing the dispersed and multidimensional game-changing in the broken city, we have seen various important social-material elements of this mobility system: toll exaction check points, road infrastructures, internet provision, international exposure, occupation rights, and slum clearing, cultural exchanges, public transport services, and indeed the identities of areas and inhabitants that shape the movements of all Rio de Janeiro inhabitants.

\section{Responses to this article can be read online at: http://www.ecologyandsociety.org/issues/responses. php/9362}

\section{Acknowledgments:}

This research was conducted within the TRANSIT project, which received funding from the European Union's Seventh Framework Programme for research, technological development, and demonstration under grant agreement no. 613169. The content of this publication does not reflect the official opinion of the European Union. Responsibility for the information and views expressed therein lies entirely with the authors.

\section{LITERATURE CITED}

Avelino, F., J. M. Wittmayer, A. Haxeltine, R. Kemp, T. O'Riordan, P. Weaver, and J. Rotmans. 2014. Game changers and transformative social innovation. The case of the economic crisis and the new economy. A deliverable of the project: "Transformative Social Innovation Theory (TRANSIT)" European Commission - 7th Framework Programme. DG Research, EU SSH.2013.3.2-1. European Commission, Brussels, Belgium. [online] URL: https://goo.gl/oaxy8v

Avelino, F., J. M. Wittmayer, B. Pel, P. Weaver, A. Dumitru, A. Haxeltine, R. Kemp, M.S. Jørgensen, T. Bauler, S. Ruijsink, and T. O'Riordan. 2017. Transformative social innovation and (dis) empowerment. Technological Forecasting and Social Change in press. http://dx.doi.org/10.1016/j.techfore.2017.05.002

Byrne, D. 2005. Complexity, configurations and cases. Theory, Culture \& Society 22(5):95-111. http://dx.doi.org/10.1177/0263276405057194

Burgos, M. B., F. A. P. Luiz, M. Cavalcanti, M. Brum, and M. Amoroso. 2011. O Efeito UPP na Percepção dos Moradores das Favelas. Desigualdade e Diversidade 11(3):49-97. 
Cajaíba-Santana, G. 2014. Social innovation: moving the field forward. A conceptual framework. Technological Forecasting \& Social Change 82:42-51. http://dx.doi.org/10.1016/j.techfore.2013.05.008

Carvalho, M. A. R. 1995. Cidade escassa e violência urbana. Violência e participação política no Rio de Janeiro. IUPERJ, Rio de Janeiro, Brasil.

Deffner, V. 2011. Geografia da desigualdade social: Uma perspectiva de geografia urbana crítica apresentada a partir do exemplo da produção social da favela em Salvador-BA. Geotextos: Revista da Pós-Graduação em Geografia da Universidade Federal da Bahia 6(2):115-137.

Dóci, G., E. Vasileiadou, and A. C. Petersen. 2015. Exploring the transition potential of renewable energy communities. Futures 66:85-95. http://dx.doi.org/10.1016/j.futures.2015.01.002

Eizaguirre, S., M. Pradel, A. Terrones, X. Martinez-Celorrio, and M. García. 2012. Multilevel governance and social cohesion: bringing back conflict in citizenship practices. Urban Studies 49 (9):1999-2016. http://dx.doi.org/10.1177/0042098012444890

Folke, C., S. R. Carpenter, B. Walker, M. Scheffer, T. Chapin, and J. Rockström. 2010. Resilience thinking: integrating resilience, adaptability and transformability. Ecology and Society 15(4):20. http://dx.doi.org/10.5751/es-03610-150420

Foucault, M., and J. Miskowiec. 1986. Of other spaces. Diacritics 16(1):22-27. http://dx.doi.org/10.2307/464648

Franz, H. W., J. Hochgerner, and J. Howaldt. 2012. Challenge social innovation: potentials for business, social entrepreneurship, welfare and civil society. Springer-Verlag, Berlin, Germany. http:// dx.doi.org/10.1007/978-3-642-32879-4

Geels, F. W., and J. Schot. 2007. Typology of sociotechnical transition pathways. Research Policy 36(3):399-417. http://dx.doi. org/10.1016/j.respol.2007.01.003

Governo do Rio de Janeiro. 2011. Estado Digital chega ainda este ano aos Complexos do Alemão e da Penha. Governo do Rio de Janeiro, Brasil. [online] URL: http://www.rj.gov.br/web/ imprensa/exibeconteudo?article-id $=379614$

Grin, J., J. Rotmans, and J. Schot. 2010. Transitions to sustainable development: new directions in the study of long term transformative change. Routledge, New York, New York, USA.

Holmes, T. 2009. Local content in Brazil: conceptual framework and methodological implications. Digithum 11(16):12-19. http:// dx.doi.org/10.7238/d.v0i11.86

Instituto Pereira Passos (IPP). 2014. Cadernos do Rio: Favelas $x$ Não Favelas. IPP, Rio de Janeiro, Brasil.

Jørgensen, U. 2012. Mapping and navigating transitions: the multi-level perspective compared with arenas of development. Research Policy 41(6):996-1010. http://dx.doi.org/10.1016/j. respol.2012.03.001

Klein, J. L., A. Camus, C. Jetté, C. Champagne, and M. Roy, editors. 2016. La transformation sociale par l'innovation sociale. Presses de l' Université de Québec, Québec, Canada.

Koonings, K., and D. Kruijt, editors. 2013. Fractured cities: social Exclusion, urban violence and contested spaces in Latin America. Zed Books, Chicago, Illinois, USA.
Lacerda, D. S. 2015. Rio de Janeiro and the divided state: analysing the political discourse on favelas. Discourse \& Society 26(1):74-94. http://dx.doi.org/10.1177/0957926514541346

Magagnin, R. C., and A. N. R. Silva. 2008. A percepção do especialista sobre o tema mobilidade urbana. Revista Transportes 16(1): 25-35. http://dx.doi.org/10.14295/transportes.v16i1.13

Misse, D. G. 2014. Cinco anos de UPP: Um breve balanço. DILEMAS: Revista de Estudos de Conflito e Controle Social 7 (3):675-700.

Moore, M.-L., O. Tjornbo, E. Enfors, C. Knapp, J. Hodbod, J. A. Baggio, A. Norström, P. Olsson and D. Biggs. 2014. Studying the complexity of change: toward an analytical framework for understanding deliberate social-ecological transformations. Ecology and Society 19(4):54. http://dx.doi.org/10.5751/ es-06966-190454

Moore, M., and F. Westley. 2011. Surmountable chasms: networks and social innovation for resilient systems. Ecology and Society 16(1):5. http://dx.doi.org/10.5751/es-03812-160105

Moulaert, F. 2009. Social innovation: institutionally embedded, territorially (re)produced. Pages 11-23 in D. MacCallum, F. Moulaert, J. Hillier, and V. Haddock, editors. Social innovation and territorial development. Ashgate, Farnham, UK.

Moulaert, F., D. MacCallun, A. Mehmood, and A. Hamdouch, editors. 2013. The international handbook on social innovation: collective action, social learning and transdisciplinary research. Edward Elgar, Cheltenham, UK. http://dx.doi.org/10.4337/978$\underline{1849809993}$

Nicholls, A., and A. Murdock. 2012. The nature of social innovation. Pages 1-30 in A. Nicholls and A. Murdock, editors. Social innovation: blurring boundaries to reconfigure markets. Palgrave Macmillan, Basingstoke, UK. http://dx.doi. org/10.1057/9780230367098 1

Observatório de Favelas. 2017. Presentation. Observatório de Favelas, Rio de Janeiro, Brasil. [online] URL: http://of.org.br/en/ apresentacao/

Pel, B. 2014. Intersections in system innovation: a nested-case methodology to study co-evolving innovation journeys Technology Analysis \& Strategic Management 26(3):307-320. http://dx.doi.org/10.1080/09537325.2013.850656

Pel, B., G. Wallenborn, and T. Bauler. 2016. Emergent transformation games: exploring social innovation agency and activation through the case of the Belgian electricity blackout threat. Ecology and Society 21(2):17. http://dx.doi.org/10.5751/ es-08346-210217

Pradel Miquel, M., M. G. Cabeza, and S. Eizaguirre Anglada. 2013. Theorizing multi-level governance in social innovation dynamics. Pages 155-168 in F. Moulaert, D. MacCallun, A. Mehmood, and A. Hamdouch, editors. The international handbook on social innovation: collective action, social learning and transdisciplinary research. Edward Elgar, Cheltenham, UK. http://dx.doi.org/10.4337/9781849809993.00023

Rodrigues, F., and E. Orlandi. 2010. Unveiling in the Rio's hills: new discourse meanings in reporting-books. Via Litterae 2 (2):401-415. 
Seyfang, G., and A. Haxeltine. 2012. Growing grassroots innovations: exploring the role of community-based initiatives in governing sustainable energy transitions. Environment and Planning C: Government and Policy 30(3):381-400. http://dx.doi. org/10.1068/c10222

Seyfang, G., and A. Smith. 2007. Grassroots innovations for sustainable development: towards a new research and policy agenda. Environmental Politics 16(4):584-603. http://dx.doi. org/10.1080/09644010701419121

Silva, D. N., A. Facina, and A. C. Lopes. 2015. Complex territories, complex circulations: the 'pacification' of the Complexo do Alemão in Rio de Janeiro. Pragmatics and Society 6(2):175-196. https://doi.org/10.1075/ps.6.2.02sil

Silva, F. M. 2011. Unidade de Policiamento Pacificadora - UPP: um processo de democratização dos espaços favelados no Rio de Janeiro? Seminário Urbanismo na Bahia-urbBA, Bahia, Brasil. [online] URL: https://goo.gl/DPUunj

Smith, A., and A. Stirling. 2010. The politics of social-ecological resilience and sustainable socio-technical transitions. Ecology and Society 15(1):11. http://dx.doi.org/10.5751/es-03218-150111

Sorj, B., and L. E. Guedes. 2005. Exclusão digital: Problemas conceituais, evidências empíricas e políticas públicas. Novos Estudos CEBRAP 72:101-117. http://dx.doi.org/10.1590/ $\underline{\mathrm{S} 0101-33002005000200006}$

Swilling, M. 2016. Africa's game changers and the catalysts of social and system innovation. Ecology and Society $21(1): 37$. http:// dx.doi.org/10.5751/ES-08226-210137

Ultramari, C., and D. Rezende. 2007. Urban resilience and slow motion disasters. City \& Time 2(3):47-64.

Unidade de Polícia Pacificadora (UPP). 2017a. UPP came to stay. About. UPP, Rio de Janeiro, Brazil. [online] URL: http://www. upprj.com/index.php/o_que e upp_us

Unidade de Polícia Pacificadora (UPP). 2017b. UPP came to stay. Video about the UPPs. UPP, Rio de Janeiro, Brazil. [online] URL: http://www.upprj.com/index.php/as upps us

Unidade de Polícia Pacificadora (UPP). 2017c. UPP came to stay. History. UPP, Rio de Janeiro, Brazil. [online] URL: http://www. upprj.com/index.php/historico us

Ureta, S. 2008. To move or not to move? Social exclusion, accessibility and daily mobility among the low-income Population in Santiago, Chile. Mobilities 3(2):269-289. http://dx. doi.org/10.1080/17450100802095338

Urry, J. 2007. Mobilities. Polity, Cambridge, UK.

Van Dyck, B., and P. Van den Broeck. 2013. Social innovation: a territorial process. Pages 131-141 in F. Moulaert, D. MacCallum, A. Mehmood, and A. Hamdouch, editors. The international handbook on social innovation: collective action, social learning and transdisciplinary research. Edward Elgar, Cheltenham, UK. http://dx.doi.org/10.4337/9781849809993.00021

Ventura, Z. 1994. Cidade Partida. Companhia das Letras, Rio de Janeiro, Brasil.
Voorberg W. H., V. J. J. M. Bekkers, and L. G. Tummers. 2015. A systematic review of co-creation and co-production: embarking on the social innovation journey. Public Management Review 17 (9):1333-1357. http://dx.doi.org/10.1080/14719037.2014.930505

Willis, G. D., and M. M. Prado. 2014. Process and pattern in institutional reforms: a case study of the police pacifying units (UPPs) in Brazil. World Development 64:232-242. http://dx.doi. org/10.1016/j.worlddev.2014.06.006

Witkamp, M. J., R. P. J. M. Raven, and L. M. M. Royakkers. 2011. Strategic niche management of social innovations: the case of social entrepreneurship. Technology Analysis \& Strategic Management 23(6):667-681. http://dx.doi.org/10.1080/09537325.2011 .585035

Yin, R. 1994. Case study research: design and methods. SAGE, Thousand Oaks, California, USA. 